\title{
Intersphincteric anal lipofilling with micro-fragmented fat tissue for the treatment of faecal incontinence: preliminary results of three patients
}

\author{
Giovanni Cestaro, Michele De Rosa, Salvatore Massa, Bruno Amato, Maurizio Gentile \\ Department of General and Miniinvasive Surgery, University of Naples Federico II, Napoli, Italy
}

Videosurgery Miniinv 2015; 10 (2): 337-341 DOI: $10.5114 /$ wiitm.2014.47435

\begin{abstract}
Faecal incontinence is a very debilitating problem. Many techniques have been proposed to treat this condition, with controversial results. Autologous transplant of fat tissue is an established procedure used for the repair of tissue damage, and recent studies revealed the potentiality of tissue regeneration by human adipose-derived stem cells. We treated this condition with the injection, in the intersphincteric anal groove, of lipoaspirate processed by an innovative technology (Lipogems). The aim of the study was to evaluate the efficacy of Lipogems injection for the treatment of faecal incontinence. In February 2014 we treated 3 patients with faecal incontinence. The surgical procedure required three phases: lipoaspiration, processing of lipoaspirate with the Lipogems system, and injection of the obtained product in the intersphincteric anal groove. An accurate proctological examination followed at 1 week, 1 month and 6 months after treatment. Each patient reported an improved Wexner incontinence score at 1 month after the procedure. We observed an increase of resting pressure (by at least $10 \mathrm{~mm} \mathrm{Hg}$ ) and thickness of the internal anal sphincter respectively at ano-rectal manometry and by ultrasound (US) evaluation at the sixth month of follow-up. Our preliminary results are encouraging, but multicentric studies with longer follow-up are needed to validate this novel technique for treatment of faecal incontinence.
\end{abstract}

Key words: faecal incontinence, intersphincteric anal groove, lipofilling.

\section{Introduction}

Faecal incontinence is a serious complaint with significant socio-economic implications: it often represents a significant limitation to daily activities, and patients become depressed due to this problem [1]. In different clinical conditions, different factors are recognized as causes of incontinence. In consequence, many different techniques, either conservative or invasive, have been proposed for the treatment, related to clinical stage: pelvic floor muscle training, biofeedback, sacral nerve stimulation, tibial nerve stimulation, sphincteroplasty, an anal plug or local devices, injection of bulking agents, and the
Secca procedure [2]. Overall results are poor and often controversial.

Autologous transplant of adipose tissue is an established procedure used for repair of a variety of tissue damage. Recent biological studies have shown that the potentiality of tissue regeneration can be enhanced using adipose-derived stem cells (ADSCs) [3]. Stem cell frequency appears to be significantly higher in adipose tissue than in bone marrow [4]. The subcutaneous adipose tissue provides a clear advantage over other sources of stem cells, due to the ease with which adipose tissue can be accessed (under local anaesthesia and with minimum patient

\section{Address for correspondence}

Giovanni Cestaro MD, Department of General and Miniinvasive Surgery, University of Naples Federico II, Via Pansini 5, 80146 Napoli, Italy, phone: +393881860680, e-mail: giovacestaro@gmail.com 
discomfort) as well as to the ease of isolating stem cells from the harvested tissue $[5,6]$.

Human adipose-derived stem cells (hADSCs) are usually localized in the stromal-vascular portion (SVp) of subcutaneous adipose tissue [7], which consists of a heterogeneous mesenchymal population of cells including adipose stromal and haematopoietic stem and progenitor cells, endothelial cells, erythrocytes, fibroblasts, lymphocytes, monocytes/macrophages, and pericytes [8]. Specifically, SVp of adipose tissue contains a multipotent cellular population with phenotypic and gene expression profiles similar to human mesenchymal stem cells (hMSCs) and pericytes [9].

Human mesenchymal stem cells are multi-potent, self-renewing cells with the capacity to differentiate, in vitro, into cells of mesenchymal origin, including osteoblasts, adipocytes, and chondrocytes, and give rise to bone, fat, cartilage, and muscle tissue in vivo [10]. Human mesenchymal stem cells have also the capacity of producing multiple trophic mediators that determine angiogenic, anti-apoptotic and anti-fibrotic responses [11].

In this study we treated 3 patients affected by faecal incontinence with the injection, in the intersphincteric anal groove, of fat tissue obtained by an innovative enzyme-free technology, named Lipogems.

\section{Case reports}

In February 2014 we treated three patients with faecal incontinence. Here we report the characteristics of the 3 cases.

\section{Case 1}

Female patient, aged 65 years, complaining of faecal incontinence for 6 years. She had a rectal prolapse and underwent a ventral rectopexy with prosthetic polypropylene mesh in 2011. Endo-anal US showed abnormality of pubo-rectal muscle and a reduced thickness of the internal sphincter; ano-rectal manometry revealed a diminished resting pressure of the internal anal sphincter.

\section{Case 2}

Female patient, aged 59 years, treated with sphincter overlapping for faecal incontinence in 2012. Nevertheless the operation did not improve this pathological condition. Endo-anal US detected hypotrophic fibres of the internal anal sphincter while ano-rectal manometry revealed a diminished resting pressure of the internal anal sphincter.

\section{Case 3}

Female patient, 73 years old, with faecal and urinary incontinence for about 5 years. The internal rectal mucosa was prolapsed, with a deep anterior rectocele and a severe bladder prolapse. Endo-anal US revealed homogeneous reduced thickness of the internal anal sphincter, and ano-rectal manometry evidenced an impaired response pressure of the external anal sphincter and a lower resting pressure of the internal anal sphincter.

\section{Operative technique}

A detailed informed consent form was signed by enrolled patients after a complete and comprehensive explanation of the experimental procedure by a member of the surgical staff. All patients were operated on by the same senior staff surgeon as a day surgery procedure under local anaesthesia. The surgical procedure consisted of three phases: 1) lipoaspiration, 2) processing of lipoaspirate, 3) injection of processed fat tissue into the intersphincteric anal groove. The presence of stainless steel marbles in the closed device is necessary to process lipoaspirate without enzymatic digestion.

The lower abdominal wall was infiltrated with adrenalin and lidocaine in a saline solution, in order to provide effective vasoconstriction and local anaesthesia. Lipoaspiration was performed with a syringe $(10 \mathrm{cc})$ to harvest about $150 \mathrm{ml}$ of fat tissue (usually needed for the Lipogems procedure) in less than 5 min (Photo 1).

The second step was based on the novel Lipogems system. This innovative technology improves the classical Coleman lipofilling technique by providing micro-fragmented and transplantable clusters of lipoaspirate. The micro-fragmentation improve their post-transplant engraftment. This system consists of a single, disposable device that progressively reduces the clusters of adipose tissue in size while a saline solution washes away oil and blood residues, which flow into a waste bag, avoiding traumatic manipulation on the cells (Photo 2). The first cluster reduction was obtained by pushing the aspirated fat tissue from the syringe into the device and through the first size filter. Then we kept the device vertical with the first size reduction filter on top, and 


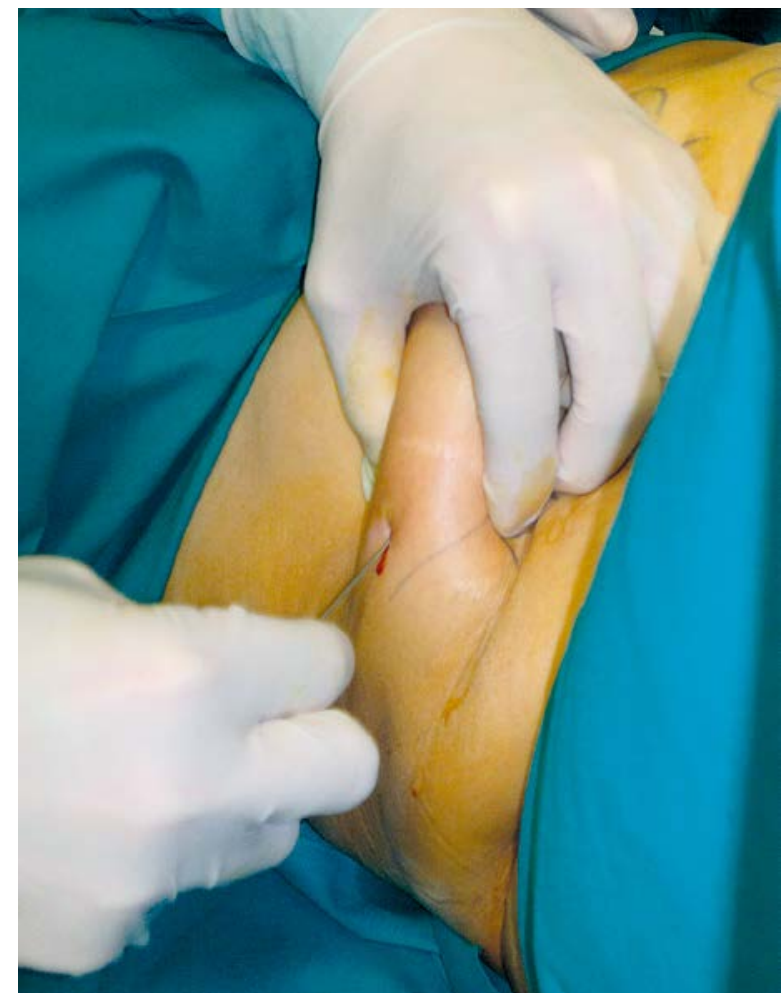

Photo 1. Lipoaspiration

it was shaken to obtain micro-clusters and to emulsify oil residues. When the solution inside the device seemed clear and the lipoaspirate true yellow, the saline flow was stopped and the device was turned upside down. The second adipose cluster reduction was obtained by passing the floating adipose clusters through the second size reduction filter by pushing additional fluid from the lower opening of the device using a syringe. The final Lipogems product was collected into $10 \mathrm{cc}$ syringes connected to the upper opening of the device.

The last step consisted in the injection of Lipogems micro-fragmented fat tissue in the intersphincteric space, with patients in the lithotomic position and under local anaesthesia (Photo 3), obtained by infiltration of the ano-perineal area with adrenaline and lidocaine saline solution.

\section{Results}

All patients underwent an accurate proctological examination 1 week, 1 month and 6 months after the surgical procedure.

End-points of the study were: pre- and post-operative evaluation of Wexner incontinence score,

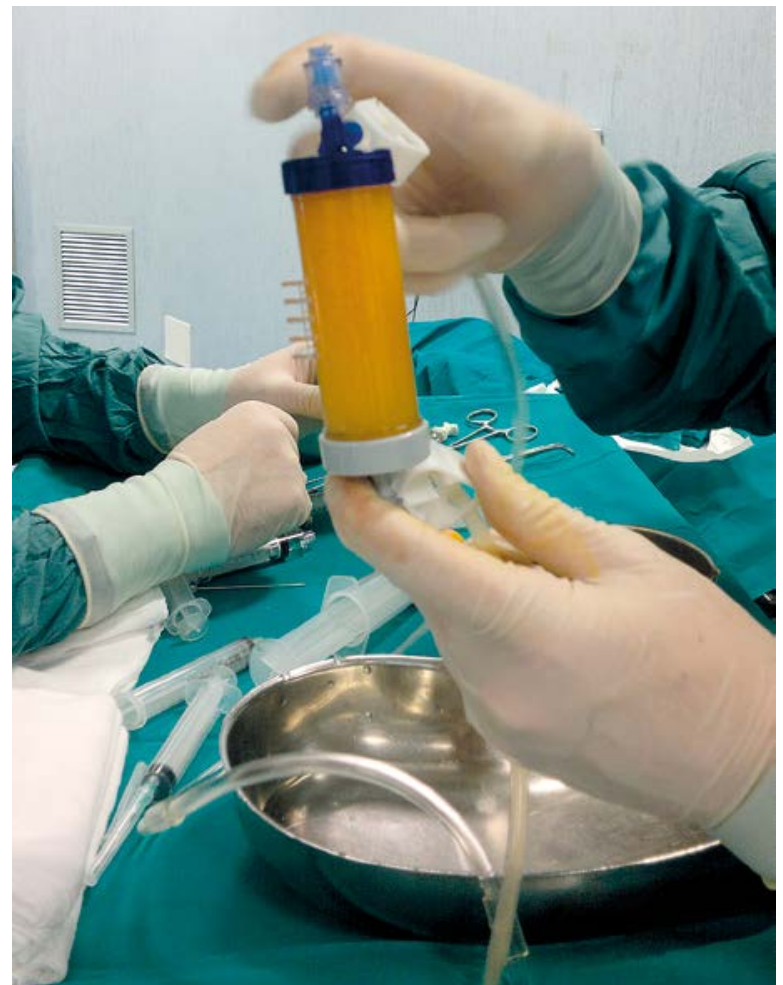

Photo 2. Lipogems device

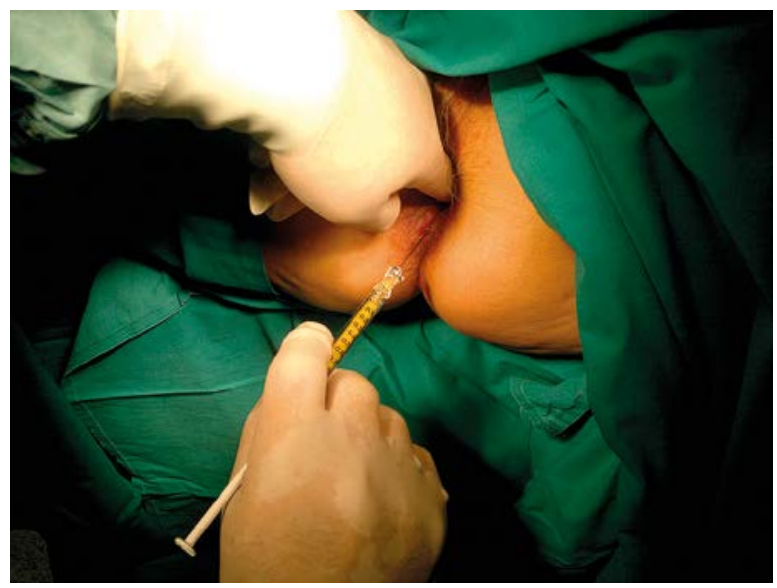

Photo 3. Anal lipofilling

ano-rectal manometry and endo-anal US evaluation at follow-up examinations. All patients showed a clinical improvement with evidence of reduction of the Wexner incontinence score from 1 month after the procedure with a significantly improved quality of lifestyle 6 months after treatment in all cases. Pre-operative Wexner and post-operative faecal incontinence scores of these 3 patients are reported in Tables I-III. 
Table I. Case 1

\begin{tabular}{|lcccccccc|}
\hline $\begin{array}{l}\text { Type } \\
\text { of incontinence }\end{array}$ & Never & Rarely & Sometimes & Usually & Always & Pre-op. & $\begin{array}{c}\text { Post-op. } \\
1 \text { month }\end{array}$ & $\begin{array}{c}\text { Post-op. } \\
6 \text { months }\end{array}$ \\
\hline Solid & 0 & 1 & 2 & 3 & 4 & 3 & 3 & 2 \\
\hline Liquid & 0 & 1 & 2 & 3 & 4 & 3 & 2 & 2 \\
\hline Gas & 0 & 1 & 2 & 3 & 4 & 3 & 3 & 2 \\
\hline Wear pad & 0 & 1 & 2 & 3 & 4 & 3 & 2 & 1 \\
\hline Lifestyle altered & 0 & 1 & 2 & 3 & 4 & 3 & 2 \\
\hline
\end{tabular}

Table II. Case 2

\begin{tabular}{|c|c|c|c|c|c|c|c|c|}
\hline $\begin{array}{l}\text { Type } \\
\text { of incontinence }\end{array}$ & Never & Rarely & Sometimes & Usually & Always & Pre-op. & $\begin{array}{l}\text { Post-op. } \\
1 \text { month }\end{array}$ & $\begin{array}{l}\text { Post-op. } \\
6 \text { months }\end{array}$ \\
\hline Solid & 0 & 1 & 2 & 3 & 4 & 3 & 2 & 2 \\
\hline Liquid & 0 & 1 & 2 & 3 & 4 & 4 & 3 & 2 \\
\hline Gas & 0 & 1 & 2 & 3 & 4 & 4 & 3 & 3 \\
\hline Wear pad & 0 & 1 & 2 & 3 & 4 & 3 & 3 & 2 \\
\hline Lifestyle altered & 0 & 1 & 2 & 3 & 4 & 4 & 3 & 2 \\
\hline
\end{tabular}

Table III. Case 3

\begin{tabular}{|c|c|c|c|c|c|c|c|c|}
\hline $\begin{array}{l}\text { Type } \\
\text { of incontinence }\end{array}$ & Never & Rarely & Sometimes & Usually & Always & Pre-op. & $\begin{array}{l}\text { Post-op. } \\
1 \text { month }\end{array}$ & $\begin{array}{l}\text { Post-op. } \\
6 \text { months }\end{array}$ \\
\hline Solid & 0 & 1 & 2 & 3 & 4 & 2 & 2 & 2 \\
\hline Liquid & 0 & 1 & 2 & 3 & 4 & 3 & 3 & 2 \\
\hline Gas & 0 & 1 & 2 & 3 & 4 & 2 & 2 & 1 \\
\hline Wear pad & 0 & 1 & 2 & 3 & 4 & 2 & 1 & 1 \\
\hline Lifestyle altered & 0 & 1 & 2 & 3 & 4 & 2 & 2 & 1 \\
\hline
\end{tabular}

Table IV. Ano-rectal manometry

\begin{tabular}{|lcc|}
\hline Patients & $\begin{array}{c}\text { Pre-op. resting } \\
\text { pressure of IAS } \\
{[\mathrm{mm} \mathrm{Hg}]}\end{array}$ & $\begin{array}{c}\text { Resting pressure of IAS } \\
\text { at } \text { th }^{\text {th }} \text {-month follow-up } \\
\text { examination [mm Hg] }\end{array}$ \\
\hline Case 1 & 51 & 62 \\
\hline Case 2 & 43 & 55 \\
\hline Case 3 & 62 & 72 \\
\hline
\end{tabular}

IAS - Internal anal sphincter.

All patients showed an increased resting pressure of the internal anal sphincter (at least $10 \mathrm{~mm}$ $\mathrm{Hg}$ ) at ano-rectal manometry after 6 months (Table IV). Moreover, endo-anal US demonstrated increased thickness of the internal anal sphincter in all cases at the same time of follow-up.
Regarding side effects, we observed only 1 case of subcutaneous lower abdominal haematoma that was spontaneously absorbed 2 months after the treatment.

\section{Discussion}

Even if the initial effect of the Lipogems product certainly depends on immediate bulking action of lipoaspirate injected into the intersphincteric space, the persistence of better anal continence probably can be explained by the capacity of human mesenchymal stem cells (hMSCs) to differentiate in muscle tissue [12]. In this paper, we have presented a simple, safe and effective day surgery procedure to treat faecal incontinence.

Classical fat tissue harvesting and injection techniques, such as Coleman lipofilling, may damage 
mature adipocytes more easily than in the case of immature stem cells: adipocytes that survive seems to be more fragile and less resistant to ischaemic damage due to revascularization following the transplant [13]. In contrast, human mesenchymal stem cells are more resistant to the trauma of both liposuction and implantation. This can be explained if we consider that immature cells require a minimal metabolic reserve and can survive longer with a minimal nutritional and oxygen amount compared to mature adipocytes [14].

Lipogems is a fat tissue derivative with the features of a minimally manipulated product that can be promptly injected in donors. Unlike the lipoaspirate that undergoes widely distributed modifications of the structure, the novel Lipogems product has a stro$\mathrm{mal} /$ vascular portion (SVp) preserved, which is an important advantage allowing better and long-lasting clinical results in the recipient site. Digestive enzymes can reduce the cell glycocalyx, a carbohydrate-rich layer lining cell plasma membranes and the vascular endothelium which plays a role in the functioning of cells receptors, enhancing cell-to-cell adhesion, reducing membrane permeability and modulating inflammatory responses to cytokines. A deficiency of glycocalyx probably impairs adhesion properties of the cells and it is not adapt to modified extracellular environments and to respond to growth factors and angiogenic proteins. The Lipogems device avoids digestion of adipose tissue by enzymes, preserving the glycocalyx [15].

Ancestor endothelial and mesenchymal stem cells derived from adipose tissue not only could be useful in plastic and reconstructive surgery, but also may be interesting for treatment of other difficult diseases. In our opinion, proctological application and mainly the treatment of faecal incontinence can be included in this list, and this study revealed unexpected good results.

\section{Conclusions}

The current study concerns only the very early experience with this innovative approach. We are going to make our follow-up longer to collect more significant data, but there is no doubt that the preliminary results are encouraging. At present we are enrolling other patients to verify the effectiveness of this novel technique. Furthermore, multicentric studies are necessary to compare intersphincteric Lipogems injection with other available techniques for treatment of faecal incontinence.

\section{Conflict of interest}

The authors declare no conflict of interest.

\section{References}

1. Cestaro G, Bracciano L, Maisto V, et al. Incontinenza fecale. Ant Med It 2011; 31: 167-70.

2. Andromanakos N, Filippou D, Skandalakis P, et al. Anorectal incontinence. Pathogenesis and choice of treatment. I Gastroint Liver Dis 2006; 15: 41-9.

3. Gimble JM, Bunnell BA, Chiu ES, Guilak F. Taking stem cells beyond discovery: a milestone in the reporting of regulatory requirements for cell therapy. Stem Cells Dev 2011; 20: 1295-6.

4. Bieback K, Kern S, Kocaömer A, et al. Comparing mesenchymal stromal cells from different human tissues: bone marrow, adipose tissue and umbilical cord blood. Biomed Mater Eng 2008; 18: S71-6.

5. Casteilla L, Planat-Bénard V, Cousin B, et al. Plasticity of adipose tissue: a promising therapeutic avenue in the treatment of cardiovascular and blood diseases? Arch Mal Coeur Vaiss 2005; 98: 922-6.

6. Oedayrajsingh-Varma MJ, van Ham SM, Knippenberg M, et al. Adipose tissue-derived mesenchymal stem cell yield and growth characteristics are affected by the tissue-harvesting procedure. Cytotherapy 2006; 8: 166-77.

7. Dicker A, Le Blanc K, Aström G, et al. Functional studies of mesenchymal stem cells derived from adult human adipose tissue. Exp Cell Res 2005; 308: 283-90.

8. Gimble J, Guilak F. Adipose-derived adult stem cells: isolation, characterization, and differentiation potential. Cytotherapy 2003; 5: 362-9.

9. Mitchell JB, McIntosh K, Zvonic S, et al. Immunophenotype of human adipose derived cells: temporal changes in stromaland stem cell-associated markers. Stem Cells 2006; 24: 376-85.

10. Pittenger MF, Mackay AM, Beck SC, et al. Multilineage potential of adult human mesenchymal stem cells. Science 1999; 284: 143-7.

11. Caplan Al, Dennis JE. Mesenchymal stem cells as trophic mediators. J Cell Biochem 2006; 98: 1076-84.

12. Tremolada C, Palmieri G, Ricordi C. Adipocyte transplantation and stem cells: plastic surgery meets regenerative medicine. Cell Transplant 2010; 19: 1217-23.

13. Von Heimburg D, Hemmrick K, Haydarlioglu S, et al. Comparison of viable cell yield from excised versus aspirated adipose tissue. Cells Tissues Organs 2004; 178: 87-92.

14. Wolter TP, Von Heimburg D, Stoffels I, et al. Cryopreservation of mature human adipocytes: in vitro measurement of viability. Ann Plast Surg 2005; 55: 408-13.

15. Bianchi F, Maioli M, Leonardi E, et al. A new nonenzymatic method and device to obtain a fat tissue derivative highly enriched in pericyte-like elements by mild mechanical forces from human lipoaspirates. Cell Transpl 2013; 22: 2063-77.

Received: 11.09.2014, accepted: 29.10.2014. 